\author{
Andrzej Sztando \\ Wroclaw University of Economics and Business \\ e-mail: andrzej@sztando.com \\ ORCID: 0000-0002-6204-9884
}

\title{
WILL SMALL TOWNS BENEFIT? EXPECTED COVID-19 PANDEMIC-INDUCED CHANGES IN SUPRALOCAL RELATIONSHIPS OF POLISH SMALL TOWNS AND PLANNED RESPONSES IN THE SUPRALOCAL PERSPECTIVE OF THEIR LOCAL DEVELOPMENT STRATEGIC GOVERNANCE
}

DOI: $10.15611 / \mathrm{pn} .2020 .10 .09$

JEL Classification: H7, O2, R5

\section{(C) 2020 Andrzej Sztando}

This work is licensed under the Creative Commons Attribution-ShareAlike 4.0 International License. To view a copy of this license, visit http://creativecommons.org/licenses/by-sa/4.0/

Quote as: Sztando, A. (2020). Will small towns benefit? Expected COVID-19 pandemic-induced changes in supralocal relationships of Polish small towns and planned responses in the supralocal perspective of their local development strategic governance. Prace Naukowe Uniwersytetu Ekonomicznego we Wrocławiu, 64(10).

\begin{abstract}
The system transformation of the 1990s for the majority of Polish small towns (STs) meant deep, unfavourable changes in the supralocal conditions of their local development (LD). As a result, they were affected by many negative phenomena. The COVID-19 pandemic has started socio-economic changes, the current predominant assessment of which is negative. Nevertheless, for Polish STs, instead of short-term reworsening their supralocal situation, these changes may turn out to be beneficial in the longer term. The article presents the expectations and observations of authorities in the field of pandemic-induced changes in the relations between their STs and the supralocal environment, as well as the planned, strategic reactions. The results of the research allowed conclusion that the changes in question in combination with the planned reactions have a significant stimulating potential in terms of LD. The article ends with recommendations for the use of information contained in the post-pandemic strategic governance of STs, in creating anti-crisis policies of states and in teaching practice.
\end{abstract}

Keywords: COVID-19 pandemic, local development, supralocal perspective of local development strategic governance, small town, Poland. 


\section{Introduction: localism and local development (LD) in both perspectives of its contemporary, correct and inseparable perception}

Localism is a strong, international, intellectual stream that appeared in the first half of the 19th century, flourished in the 1970s and 1980s, and is globally strongly present to this day. It proves the possibilities, benefits and necessity of creating the development of supralocal systems to a significant extent based on the subjectively-treated local communities and activated local, tangible and intangible resources. In many countries, it was and is the basis for the decentralization of power and public development policies, and in Poland it was additionally one of the determinants of its systemic transformation in the 1990s from the socialist paradigm to the democratic and market oriented one.

The basic category of localism is local development. In spite (or maybe because) of being many times defined and discussed in literature, used in media and the daily activities of public administration, as well as in the common language, it is still frequently, incorrectly or incompletely understood. Therefore, further considerations concerning its strategic governance must be preceded by its explanation. What is most important in this respect, is that the category of local development (LD) should be perceived at the same time in the two inseparable ways described below.

The first way - local - consists in understanding it as a non-unified, long-term, self-sustaining and multidimensional process of transforming the structures of the local system and the connections between them, and also their connections with diverse elements of the environment, co-forming desirable supralocal processes created in a participative, planned and coordinated manner and in accordance with the idea of integrated order, above all through and in the interest of the local community, as well as through consensus-based mobilization of mainly endogenous factors. The local system is most often equated with the commune, and therefore LD in the local perspective can be identified with the commune's development. The purpose of LD perceived in such a way is to increase the broadly understood quality of life of the local community, but at the same time generating values desirable in the supralocal environment. Most definitions express this kind of LD perception, e.g. (Marques, 2009, p. 3; Milán-García, Uribe-Toril, Ruiz-Real, and Valenciano, 2019, pp. 2-3).

The second way - supralocal - of perceiving LD, means its conceptualization and identification at the level of regions, individual states, associations or other groups of states (e.g. the EU), and even on a global scale. In this perspective it denotes such transformations of the structures of the above-mentioned supralocal systems and relationships between these structures and elements of their environment, which are in large part the result of LD processes occurring in the communes that make up them. However, it is not only about the development processes of many communes and the effects of these processes combined into simple, supralocal 'sums'. Most importantly, that as a consequence of network interactions between 
developing economies, communities and the environment of communes, as well as between those and other supralocal entities (e.g. societies, companies, public and non-governmental organizations) existing and new, regional, state and global (i.e. supralocal) development processes are initiated, intensified and protected. Simplifying and generalizing, LD in this approach means the transformation of LD processes taking place in communes into supralocal development processes. The goal of LD understood in this way is to increase the life quality of supralocal societies. Thus LD in this perspective is also treated as an important idea for the development of the contemporary state and its regions, as well as international communities. Yet a supralocal way of perceiving LD appears rarely in the literature, e.g. (Rezsohazy, 1988, p. 17; Szajnowska-Wysocka, 2009, p. 85). Local and supralocal categories of LD together form a paradigm of LD based on contemporary localism, complementary to the paradigm of regional development and incorporated by the paradigm of territorial development (see e.g. O’Brien, Sykes, and Shaw, 2015, p. 88).

\section{Theoretical basis: local development strategic governance (LDSG) and its supralocal perspective (SPLDSG)}

The general postulate and specific proposals of localism for creating LD in both its dimensions have evolved in connection with the dynamic development of public governance as a science and practice of local and supralocal authorities in recent decades. Public governance (originally called public management) was initially referred to individual public institutions which were supposed to achieve certain objectives. The latter approaches also associated them with networks or other groups of such institutions. Currently it is increasingly linked with society and its organized actions to achieve collective objectives strictly based not only on economic rationality, but also that of public choice, incorporating e.g. economic, ecological, scientific or even religious ones. This trend covers the category of local development governance. This refers to LD in a local perspective, i.e. to the abovedefined, multidimensional process occurring on a local scale, whose participants represent local enterprises, public institutions, NGOs, elements of ecosystems, and residents - not just local authorities and organizations subordinated to them, creating together a municipal system (commune as public entity). This means taking advantage of this municipal system to stimulate transformations of the commune' structures, the mutual relationships between them and with the diverse elements of this the environment, thus representing LD.

The practice of LD governance is complex, difficult and multidimensionally expansive. In this regard, since its inception, researchers and practitioners of public governance search for effective and efficient patterns of its implementation. One of them is strategic governance, which has its roots in strategic management evolved in the sphere of business. Despite the fact that LD strategies are prepared and adopted in many countries, the concept LD strategic governance (LDSG) is very rarely defined 
in literature. The related concepts of 'strategic governance of municipal development' and 'strategic management of a commune' are more often defined, but the emphasis is placed in them on the stages of strategic approach, or on holistic approach to governance of a municipal system, rather than on transformations of commune structures and relationships. The essence of municipal LDSG is, however, the complex impact of the commune authorities on these structures and relationships in accordance with the stages of strategic approach and by means of the organizations subordinated to them, but ensuring that changes of these structures and relationships have the characteristics of LD, perceived from the local perspective (Sztando, 2017b, p. 66).

In the last dozen or so years, in LDSG, more and more attention has been paid to the relationships linking the commune with the supralocal environment and to shaping these relationships. Their importance in LD is constantly growing as a result of the dramatic increase in their number, diversity and variability, resulting from globalization, technological progress, international politics, human and capital migrations, climate change, diffusion and clashes of cultures, and other supralocal mega-processes. The first research in this area included studies of supralocal premise of pro-economic decisions made by some municipalities from Canada (Frisken and Wolfson, 2000) and the USA (Lewis, 2001), barriers to the implementation of LD policies in Great Britain taking into account the global context (Blair and Evans, 2004), and reactions to the global challenges of the local authorities in selected Chinese cities (Kuotsai, 2009). In Poland the first comprehensive research of this type was carried out in 2017. One of their results is - based on direction criteria for these relationships along with their impact on commune LD - the typology of the relationships discussed and the corresponding, desirable qualities of LDSG (Sztando, 2017a, pp. 61-66) (see Figure 1) which were adopted as the theoretical basis and determinant framework of the research presented below.

The first type of said relationships represents those extending from the inside of commune towards its supralocal environment and consist in supralocal valorisation of local values, such as products, services, innovations, information, knowledge, elements of social and human capital, residents, elements of natural environment, culture components etc. Supralocal valorisation stands for gaining by these values the broadly perceived value (i.e. not just a tangible one) in a supralocal environment, as well as the increasing level of their supralocal dissemination. This is why they have been called valorisation relationships, and because owing to them communes obtain either tangible or intangible equivalents, advantageous for their development, these relationships are positive and desirable. With regard to these relationships, the LDSG should be characterized by exogenous utilitarianness. This means constant searching by local authorities for possibilities for the supralocal valorisation of local values as well as money initiating and supporting such valorisation. This directly results in using local values to meet the needs of supralocal entities and collectivities, while indirectly in gaining in return the locally desirable supralocal values, which constitute the commune LD factors. Exogenous utilitarianness must, 


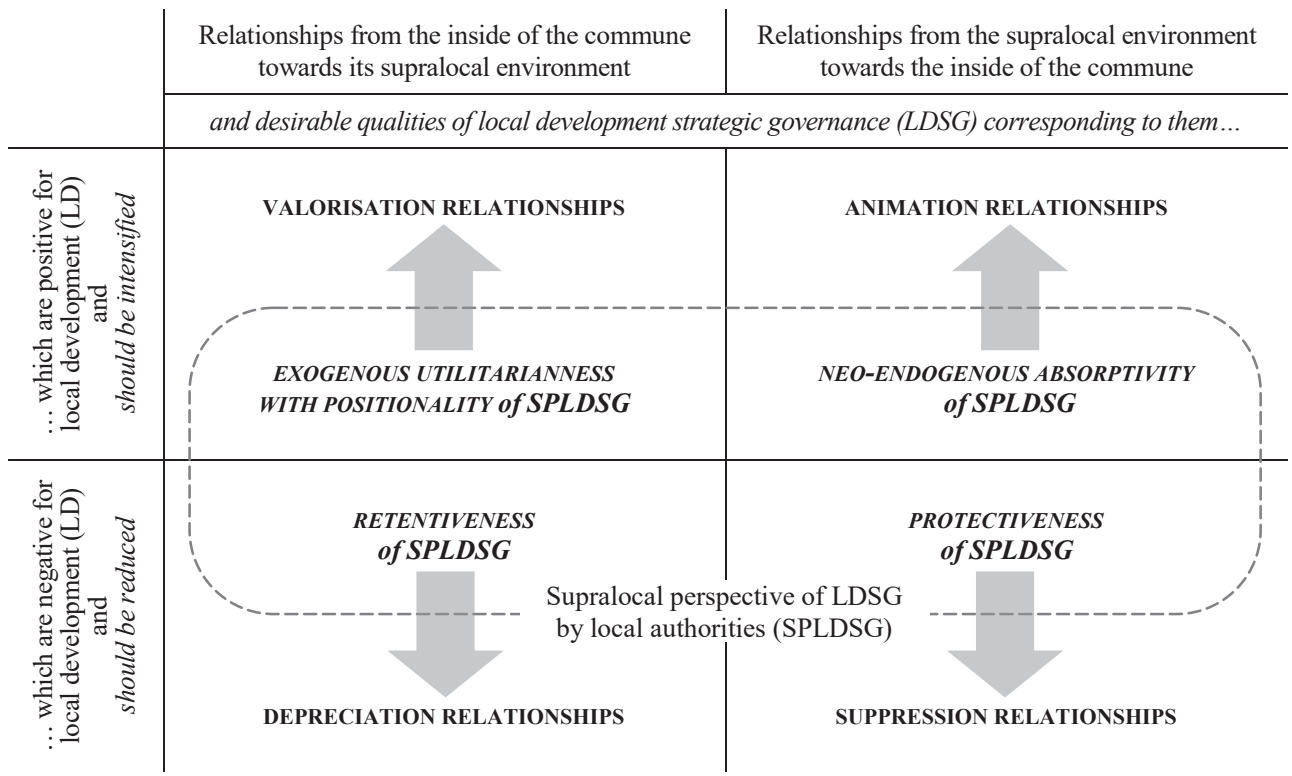

Fig. 1. Supralocal relationships of the commune with desirable qualities of local development strategic governance (LDSG) corresponding to them as components of supralocal perspective of LDSG (SPLDSG).

Source: own study based on (Sztando, 2017a, pp. 61-66, 94-102).

however, be accompanied by positionality, which means concentrating during intensifying valorisation relationships on defining for the commune, and holding by it a limited set of competitive and complementary positions towards the supralocal environment. Due to the limited resources at the disposal of both local authorities and the commune, supporting all active and potential valorisation relationships would be ineffective and inefficient. Therefore, it is necessary to make choices, i.e. to strive to assign and occupy an intentional socio-economic positions (territorial specializations) with the commune in a supralocal environment.

The second group of relationships covers those also favourable for LD, however progressing in opposite direction, i.e. from the supralocal environment towards the commune. They consist in influx of tangible and intangible supralocal values ( and other material capital, services, knowledge, information, innovations, new inhabitants, natural resources, energy sources, culture, favourable decisions of supralocal authorities) to the commune, which are factors of its LD. They also consist in prodevelopmental influences of supralocal factors on the local values as well as their local and supralocal relationships. Taking into account their activating, and their reinforcing, innovative and mobilizing impact, they have been assessed as desirable and called animation relationships. A feature that LDSG should have in relation to these relationships is neo-endogenous absorptivity, which, in simple terms, can 
be equated with the constant focus of local authorities on obtaining LD factors for a commune from its supralocal environment. Attracting this simple reinforcement is important, however obtaining such factors along with linking them to local values (i.e. endogenous ones) have a stronger creative potential. This results in the local replication of supralocal values or in the development of local innovations (new values), indissolubly associated with the commune and permanently making for its LD (such attention was not paid in the past to the self-sustainability of LD processes induced by absorption, so to distinguish the new approach the prefix 'neo' is added to the adjective 'endogenic'). It is also important to attract exogenous factors of initiation, 'start-up' temporal support or impulse stimulation of LD processes.

Contrary to the above discussed, the third type - suppression relationships - are negative for LD. They are progressing towards the inside of the commune from its supralocal environment and most often consist in the unfavourable modification, reduction or total elimination of local values by supralocal factors (e.g. influx of supralocal crime, pollution, harmful patterns of social behaviour, flood waters, burdensome transport transit). Sometimes the burdens or limitations imposed on the commune by supralocal authorities enforcing its supralocal usefulness and its development products, as well as enforcing local respect for the supralocal values (e.g. unique ecosystems or state critical infrastructure). It is therefore clear that, to the possible extent, the LDSG run by local authorities should focus on detecting, reducing or inhibiting suppression relationships which damage the base for the commune LD or are perceived by the local community as inalienable components of its identity. This trait which expresses this aspiration is called protectiveness. It is worth mentioning that in a situation where direct defence is not possible or legal, protectiveness means persuading (lobbying) supralocal authorities towards alternative visions of the role played by the commune or group of communes in the supralocal (e.g. country) development processes.

The fourth group includes relationships which are also negative for the commune's LD, and progressing in the opposite direction, i.e. from within towards its supralocal environment. They consist in non-equivalent loss of local values in favour of this environment (e.g. relocation of economic entities and their capital outside the commune, emigration of residents, overexploitation of local natural resources by global companies) as well as non-equivalent supralocal (para) fiscal burdens and other public tributes (e.g. PIT and CIT taxes), thus they were called depreciation relationships. A desirable feature of LDSG, corresponding to depreciation relationships, is retentiveness. It expresses constant identifying, preventing and limiting by local authorities the non-equivalent loss of local values in favour of supralocal environment. Analogically to protectiveness, it refers to the most important local values and in the case of evidently non-equivalent burdens or tributes, persuading and lobbying remain the only options.

The presented characteristics of the LDSG of local authorities, along with their relevant interventions and other actions, altogether constitute the supralocal 
perspective of LDSG (SPLDSG), whose weight for LD is significant. The activities carried out within its framework enlarge the volume of LD factors obtained from the supralocal environment for the social, economic and environmental (natural) structures of the commune. Such activities also combine these factors with the structures of the commune, and thus increase the scale of their positive impact, strengthen this impact and its effects as well as activate the these structures. Moreover they disseminate local approval for these factors and their implementation and also modify them profitably, hence developing especially desirable local innovations. In addition, activities within the framework of SPLDSG protect a commune against supralocal destimulants influencing negatively its structures and relationships, as well as reduce the non-equivalent loss of local values responsible for LD in favour of the supralocal environment. Sometimes they also constitute a form of defence against the unfavourable decisions made by regional or national authorities and other key entities, and also the preventive measures against them. SPLDSG is also important for LD perceived from the supralocal perspective. The activities that belong to it support transferring the locally created or modified values to the supralocal arena, useful for supralocal human collectivities and organized forms of their activity, as well as include economies, communities and ecosystems of communes into supralocal development processes.

\section{Pandemic-induced research gap in the supralocal relationships of Polish small towns, and their SPLDSG responses as well as significance}

As part of the systemic transformation, with the use of the then flourishing ideas of localism and pre-communist, municipal, national long-term traditions, from 1990 the new, democratic state authorities divided the territory of Poland into communes (today there are 2477 of them) and entrusted their development governance to a large extent to local authorities elected by their inhabitants (eight years later, counties and regions with their authorities and tasks were added together, and are referred to as self-governments). At the same time, local authorities were provided with the necessary decision-making autonomy, legal instruments, legal protection, financial resources and responsibility to complete this mission. Due to its complexity and continuing popularization of localism and multilevel governance, Polish local authorities began to experiment with the construction and implementation of LD strategies just a few years after their establishment. Although the motives for adopting these strategies are not always fully consistent with those postulated by specialists, today almost every Polish commune has an officially adopted LD strategy (although it was neither mandatory nor legally regulated), and to a greater or lesser extent conducts LDSG on its basis.

When developing and implementing LD strategies, all Polish local authorities have always taken into account the relationships linking the economies, communities and ecosystems of their communes with the supralocal environment. A special 
group among them are the authorities of communes covering small towns, which in Poland are most often understood as those with 5 to 20 thousand residents, and whose total population is $15.8 \%$ of the urban and $10.4 \%$ of the entire population of this country.

The uniqueness of this group of local authorities lies in the fact that from the beginning of Poland's systemic transformation of the 1990s, most of their small towns (with the exception of those directly adjacent to large cities or are well-known tourist resorts) have undergone and are still subject to structural development problems resulting in their regression or stagnation. This is manifested by a decline in the population, unemployment, decapitalization of the housing, production, technical and social infrastructure, a decline in the aesthetics of space, migration of enterprises, increase in crime, alcoholism and other social pathologies, reduction of residents' income, limitation of availability and quality services, monuments falling into ruin and other negative phenomena. In the Polish scientific literature this complex of unfavourable processes was defined as the shrinking of small towns and many studies were devoted to it (Kantor-Pietraga, Krzysztofik, and Runge, 2012).

The reasons for these negative phenomena in small towns were primarily the regression of their relationships of:

- valorisation, as a result of e.g.: the market collapse or arbitrary liquidation of state-owned enterprises previously dominant in their economies; slump in demand for servicing the surrounding rural areas, especially agriculture; administrative liquidation of offices located therein and other public entities of social infrastructure serving their subregional surroundings;

- animation, as a result of e.g.: cancelling transport services and abandoning the logistic infrastructure connecting them with environment; cutting state and large corporations investments in their technical infrastructure; the disappearance of the inflow of commercial external investment; suspension of state support granted to local enterprises;

with the simultaneous development of their relationships of:

- suppression, through e.g.: establishing by state authorities in a significant part of their area restrictive, legal forms of nature protection; the influx of large retail outlets eliminating local small trade; the influx of organized crime; the influx of 'McDonaldised' supralocal culture that supersedes traditional, local cultural values; the influx of highly demanding attitudes, consumerist lifestyle, patterns of dishonesty and selfishness, social indifference, deep distrust of society and its institutions, as well as avoiding and using the law contrary to the intention of the legislators;

- depreciation, through e.g.: permanent migration of local inhabitants to large Polish cities and abroad; outward relocation of local companies; top-down centralization of the local public institutions serving the residents, NGOs and companies; taking away their cultural goods; predatory exploitation of leased out public property or the natural resources located in them (Sztando, 2017a, pp. 110-115). 
It is also worth mentioning the polarising-diffusion model of socio-economic policy used on a long-term basis by the Polish state authorities. It is estimated that in general this has contributed to the development of the country, especially large cities and agglomerations, but, contrary to intentions, at the same time it greatly contributed to the deterioration of many supralocal relationships and the shrinkage of small towns.

In such a strategic situation, the SPLDSG implemented by the authorities of Polish small towns in recent years has usually had a niche-absorption-defensive character. They focused on the search and development (exogenous utilitarianness) of these one, up to few, carefully selected (positionality), exogenous functions of their economies, which could at least partially replace the lost functions, while at the same time concentrated on desperately attracting any external investors and financial aid from the EU (neo-endogenous absorptivity), as well as on hard-line defence (protectiveness and retentiveness) of these most significant local values that have not yet been devalued or lost. This strategy allowed some small towns to contain degradation, and some even to develop in general, but in view of the persistent and deepening unfavourable supralocal relationships it brought only partial successes and relative stagnation to many others, and sometimes only a slowdown in regression. However, it was treated as having no better alternative (Sztando, 2017a, pp. 116-120, 237-242).

At the end of 2019 the COVID-19 pandemic (hereinafter also referred to as a pandemic), caused by the previously unknown SARS-CoV-2 virus (hereinafter also referred to as a virus), began in Wuhan, China. As of 10 August 2020 (the date of completion of work on this article), approximately 19.7 million cases were registered in 188 countries and territories, including approximately 0.73 million deaths, with WHO estimating that the pandemic is only in the initial phase and can result in hundreds of millions of new cases and tens of millions of deaths (WHO, 2020, pp. 1-2). Coupled with its health ramifications, the pandemic and the responses of public authorities, businesses and societies have induced and continue to induce many unexpected social, economic and environmental changes, while at the same time being quick, profound and seminal, occurring in all spatial dimensions, and as a whole unprecedented in the history of mankind. From the genre point of view, these changes include: high prioritization of social distancing; administrative restriction of the liberties of billions of people; long-term confinement to the place of residence; increased ratio of telework; rapid development of teleservices including online education; collapse of demand for passenger transport (especially international); suspension or serious limitation of a number of services, namely cultural, recreational, hotel, tourism, restaurant, leisure and social; disruption of global supply chains; breakdown of economic growth; strong increase in deficits of public budgets; intense fluctuations of currency exchange rates and stock market prices; a sharp increase in unemployment and the demand for social assistance; a decline in the purchasing power of the population; an increase in the money 
supply; abrupt changes in the demand for various products and services, and much much more.

Starting from mid-March 2020, when the pandemic and its effects reached Poland, the described changes began to include multidimensional relations between small towns and the supralocal environment. It was quickly noted not only by local authorities and scientists, but also by municipal managers, economic journalists and entrepreneurs. First, attention was drawn to the changes negative for LD, both those that had already occurred as a result of the "lockdown-type" measures and those that would inevitably come later (Bukowski, 2020). Soon, however, assumptions and voices emerged that, apart from being unfavourable, the pandemic may also bring favourable changes to the supralocal relationships of small towns (see e.g. Sobańska-Cwalina, 2020). Nevertheless, there was no doubt that, in general, these changes are or will be far-reaching and seminal, and therefore require diagnosis and forecasting, and then the appropriate responses in the SPLDSG. Appropriately early and adequate responses may not only limit or compensate for these new supralocal relationships which are unfavourable for LD, but could also strengthen and use favourable ones. Debates related to this subject are an integral part of the Polish public discourse devoted to the socio-economic effects of the pandemic and the desired responses to them (see e.g. Gniadkowski, 2020, p. 40-41).

The entirety of the changes in the supralocal relationships of Polish small towns will be possible to know and evaluate in detail only when they reach their new states, which will happen long after the pandemic ends, i.e. not earlier than in a few years' time. The immediate reformulation of the SPLDSG must therefore be based on current observations and the satisfactory forecasts of these changes and their potential consequences. The authorities of small towns try to acquire and conduct such observations and forecasts on their own, but this is accompanied by their shortage and uncertainty as to their credibility. It would be useful to know what changes and on what basis all authorities of this type expect and how they intend to respond to them in the SPLDSG. Such knowledge could also be useful to some extent for the state authorities. They could use it to include in their anti-crisis policy tools that would help small towns quickly and effectively react to pandemic-induced changes in their environment. This would contribute to the overall success of this policy and the knowledge would also be of scientific importance. It could be used to find answers to the questions of how the pandemic will affect the overall situation of Polish small towns and whether they may stop shrinking as a result. It would also be a study of LDSG conducted by a group of similar communes in conditions of rapid, structural changes in their relationships with the supralocal environment. However, before the first research of this kind described below, such knowledge was not available. The author considered this situation as a research gap of great practical and theoretical importance and decided to take part in filling it by implementing the research project presented below. 


\section{Objectives, assumptions, population, source of information, method and course of research}

Taking into account the characterized research gap, five research goals were set:

1) identification of the most common expectations (or observations) of the authorities of small towns on (of) pandemic-induced, key changes in the relationships between these towns and their supralocal environment, which will take place in the next two to three years (or have already taken place),

2) identification of the opinions of those local authorities on the basis of the perceived expectations,

3) identification of the most often planned (or already implemented) by the above-mentioned authorities responses within SPLDSG (i.e. exogenous utilitarianness and positionality, neo-endogenous absorptivity, protectiveness, retentiveness) to expected (or observed) key changes in supralocal relationships, described above.

4) identification of the main characteristics of the overall picture of those expectations (and observations) and the planned (or already implemented) responses in the SPLDSG,

5) general assessment of the pro-developmental potential of differences between the previous and expected (or already observed), pandemic-induced, supralocal relationships of small towns and the corresponding responses planned by their authorities in SPLDSG.

Although awareness of the research gap appeared in March 2020, it was decided to conduct research only three months after the pandemic outbreak in Poland. This temporary delay was chosen as that guaranteeing a much higher value and accuracy of expectations than those which would be formulated immediately after the outbreak. In the first weeks of the pandemic, when the state authorities announced an immediate lockdown of the country, the local authorities focused on the current internal situation and as yet have not reformulated their SPLDSG. They ensured epidemic safety of residents, secured the functioning of their own administration, switched municipal schools to distance learning and other municipal entities to a remote or modified provision of the most important public services. At that time there was a very high uncertainty as to the directions of the supralocal changes, fuelled by highly disturbing, often contradictory and sometimes even panic-provoking information coming from the world. There was also very high uncertainty as to which of the sudden and deep changes in supralocal relationships that occurred at the beginning of the outbreak would prove to be permanent, and which only temporary, and what would be their consequences. A much more precise diagnosis and projection of the own situation, as well as the creation of drafts of new strategic responses, started only after two to three months when the nature of the pandemic was slightly better understood, numerous domestic and foreign analyses of the multidimensional changes and their forecasts became available, the policy response of the state authorities became detailed and implemented, and the media, institutional and scientific forums for debates brought 
the first consensuses and promotion of good practices in crisis, thinking patterns, strategic choices, etc.

The local authorities of Polish communes, including small towns, are composed of two integrated bodies - decision-making-control and executive. The first is the council that makes the most important decisions regarding the implementation of the commune's tasks and controls their execution by the executive body, and which consists of a dozen to several dozen councillors elected by the inhabitants. The executive body is the 'wójt' (Ger. 'Vogt', the head in rural communes, which include only villages and smaller settlements) or the mayor (in: 1. urban-rural communes, which include one town and villages; 2 . urban communes, one town only), or the city president (in large urban communes, one city only with a minimum of 100 thousand inhabitants), who is elected by the residents and implements the council's decisions and prepares most of their drafts. The choice of mayors as sources of information about the expectations and plans of entire authorities of small towns was due to three reasons. First, according to Polish law, the commune is represented by its executive body. Secondly, as a result of legal regulations and local community expectations, mayors in Poland are the main designers, creators, integrators and executors, a real "spiritus movens" of the LDSG. Therefore, out of all the members of local authorities, they are the ones who have the most knowledge about the supralocal relationships of their towns and are the main planners and implementers activities influencing these relations. Councils are usually more passive in this respect, and therefore they monitor and plan the shaping of supralocal relationships much less frequently and more superficially (cf. Bober et al., 2013, pp. 29, 96). Thirdly, by cooperating with councils on an ongoing basis, mayors know their opinions about the supralocal situation of their towns and are aware of what strategic proposals they may or may not accept.

The research population was therefore the local authorities of communes covering small towns, represented by their mayors, whose number on the day of starting the research was 366 . The research was carried out from 15 June to 14 July 2020 on a representative, randomly selected sample of 55 of the local authorities under study, which made up $15 \%$ of the population. The method of diagnostic survey was selected to obtain information and it was applied using the CATI technique. The research was preceded by the publication on 4 April 2020 of the author's interview at the beginning of the pandemic in Poland to the self-government fortnightly magazine "Wspólnota", reaching all local authorities in this country. It concerned pandemic-induced changes in the strategic situation of communes, and the discussions with local authorities that followed were used in the construction and testing of the questionnaire. It also contributed to the fact that none of the mayors refused to be questioned and to their involvement in providing comprehensive answers. 


\section{Research results}

\subsection{Expected (or observed) changes in valorisation relationships and planned response in exogenous utilitarianness and positionality of the SPLDSG}

Among the most discussed effects of the pandemic in the media and by scientists is the decline in production, trade and demand. Almost all of the mayors interviewed indicated that these declines also applied to some products manufactured for the supralocal environment in their towns, but only $34.5 \%$ of them expect them to be important for the local economy. They represent cities with developed automotive, machine, mining and some light industries that have been severely affected by the restrictions, however they do not anticipate the decline in the valorisation relationship as being long-lasting and therefore do not plan any serious SPLDSG adjustments. Moreover, they emphasised that the affected producers are mostly subsidiaries of large capital groups, and the support that could be provided by communes would not change their situation. In the case of small, local producers, they plan to support them with small ad-hoc tax exemptions. However, it is worth mentioning that the weakening of this type of relationships and the limitation of endogenous activity resulted in a sharp fall of the budget revenues of all Polish communes. According to the estimates of municipal associations, the average annual decrease in budget revenues of communes in 2020 will amount to a few percent.

All the other expected key changes in the valorisation relationships are changes favourable to small towns. Among them, mayors most often indicated the long-term development of touristic services $(50.9 \%)$ provided in their town for the benefit of the inhabitants of mainly the regional surroundings, especially from nearby large cities, but also from other parts of the country and neighbouring countries, in particular Germany. The following reasons were given as justification. As a result of restrictions introduced by most governments, cuts and constraints in international passenger transport, prioritization of social distance, fears of infection with SARS-CoV-2 visiting countries which are the following main foreign tourist destinations for Poles, and at the same time most affected by the pandemic (Spain, Italy, France, Egypt, Turkey). As well as the crisis reduction of the propensity to bear higher costs of foreign tourism, the change in tourism demand is already being observed and will continue to deepen. This will consist in shifting the demand from mass tourism (realised in medium or large hotels and holiday centres, in large and wellknown resorts, in connection with mass events and as part of the services of largescale tour operators) to more individualized tourism (planned and organized more independently and with avoiding crowds, namely with the use of small guesthouses, agrotouristic farms, small holiday villages and campsites, and short-term rental of private apartments), and at the same time more local and regional (avoiding mass transport, especially airplanes and using one's own car that provides insulation, while shortening the travel distance to reduce travel time and costs). At the same time, 
Polish small towns and their local surroundings have, although usually underused so far, many tourist advantages (cultural, natural, historical, social, infrastructural, etc.), including those matching the new form of tourism demand (short distance, easy access, low prices, high dispersion of numerous tourist service points ensuring social distancing and individualization of own activities). The authorities surveyed noted the first symptoms of this new tourist movement shortly after the lockdown-type measures were reduced. The state's policy of crisis support for the national tourism industry is also favourable here, including the granting of a voucher worth PLN 500 for each child under 18 valid until 31 March 2022 for tourist services provided in Poland. Thus almost all of the surveyed local authorities plan to intensify the exogenous utilitarianness of the SPLDSG in relation to this newly restructuring valorisation relationship. Among the intentions for immediate strategic actions, the most frequently mentioned were: construction of public touristic infrastructure (e.g. bike paths, bathing areas, open recreational areas), revitalization of historic districts, changes to zoning plans favouring private investments in tourism, increasing the involvement of municipal cultural and sports institutions in meeting the needs of tourists, intensification of national tourism promotion and search for external investors active in tourism industry. Although only $3.6 \%$ of mayors assessed that as a result of the pandemic and the planned reactions, tourism may become a dominant sector of the local economy (a territorial specialization of the town), $16.4 \%$ said that its share may increase to a level comparable to that of other exogenous functions. All the others indicated that they found it difficult to estimate the achievable growth, but considered it appropriate to highlight it in the SPLDSG.

The second largest number of responses was the relationship of telework performed by the residents employed by supralocal employers. Its long-term growth is expected by almost a third (30.9\%) of local authorities of small towns. In the initial phase of the pandemic, the governments of many countries, including Poland, introduced severe restrictions on social contacts, including those related to work. As a result, with the active acceptance of employers, millions of Poles started to work partially or fully remotely within a dozen or so days, mainly using the Internet and digital teamwork platforms. The scale and speed of this change, as in some other countries, were therefore unprecedented. In the opinion of the respondents, widely shared, the most revolutionary, however, was the mental dimension of this change. Remote work tools were available before, but due to bad habits, ignorance and prejudice, they were used on a larger scale only in certain sectors. The pandemic made millions of people aware that in many professions (especially innovative, creative, highly professional and bringing high added value to work processes) telework is a real, at least partial alternative to working in the company's headquarters, and sometimes even better, because it is more convenient, safer and cheaper for both parties of the employment relationship, hence it is worth continuing it even after the restrictions are lifted. A few months of confinement in their homes for millions of people has brought another mental change. Some of them who have 
sufficient private space, especially with open space, found it pleasant, beneficial and conducive to achieving work-life balance. According to the respondents, in conjunction with the accompanying processes (1. Polish small towns have made up in a significant part for the backwardness in the technical and social infrastructure in recent years; 2. the Slow City strategy is becoming popular among the authorities, in response to its popularity among highly qualified people as the idea of a modern, sustainable life, more local, closer to nature, an alternative to big-city stress, rush and homogenisation; 3 . the remote accessibility of the traditionally large-city values is increasing thanks to e-commerce and the Internet and other online services; 4. public transport linking small and large cities is improving; 5. the mass implementation of 5G technology is closer; 6 . the Polish government announced the introduction of telework to the labour code), the indicated changes in awareness mean for small towns that in the new reality, some of their inhabitants can comfortably live there performing telework for distant companies from large cities, travelling to them only from time to time, i.e. acceptably rarely, while in the old reality they would have had to travel almost every day, i.e. unacceptably often. The planned response within the exogenous utilitarianness of the SPLDSG to the expected development of the discussed relationship consists, therefore, in the multidimensional facilitation of telework and the removal of logistical barriers, while continuing to increase the living advantages. The planned projects included supporting the development of a local broadband network infrastructure, creating co-working spaces and innovative micro-entrepreneurship incubators, as well as lobbying for and supporting the reactivation of railway connections that were frequently closed down in the 1990s.

The third of the expected key changes in the valorisation relationships of small towns is the development of their new exogenous industrial production functions. Such expectations were expressed by $10.9 \%$ of mayors, but none of them was ready to specify precisely the type of these functions. On the other hand, they perceive the phenomenon of pandemic disturbances in global supply chains, especially linking Western Europe and cheap labour in Asian countries, and believe that this will result in shifting production sites to Poland (closer, safer in this respect and with an increasing ratio of productivity to labour costs), not only to large and medium-sized cities, but also to small ones or their close vicinity. These expectations are too general to entail changes to the exogenous utilitarianness of the SPLDSG. However, they turned out to be sufficient to change its neo-endogenous absorptivity, as discussed in the next section.

The remaining expectations regarding the key changes in the valorisation relationships were expressed only in a few cases. Three mayors expect an intensification of trade serving the subregional, rural, agricultural environment, resulting from the pandemic innovations of the largest supermarket chains, consisting in concluding contracts with local food producers to supply a few, or even only one supermarket in the chain. This is to increase the security of supply by diversifying its sources, so far dominated by large, often global suppliers, and at the same time 
to make supermarkets more local for local communities. Two mayors pointed to the highly probable increase in the online streaming of cultural content produced in their towns to national audiences. During the lockdown, municipal cultural institutions also switched to distance activities, and it turned out that the most artistically creative of them gained an audience far beyond their locations.

\subsection{Expected (or observed) changes in animation relationships and planned response in neo-endogenous absorptiveness of SPLDSG}

Among the pandemic-induced key changes in the animation relationships, financial aid for economic entities (including sole traders) and contractors, already observed and expected by small towns' authorities in the future, forming part of the state' large package of instruments protecting the economy under the name of "Anti-Crisis Shield" (ACS), is clearly dominant. This relationship takes the form of idle time pay, co-financing of employee salaries and partially forgivable loans, the total value of which amounted to about PLN 60 billion from its introduction on 1 April 2020 up to the end of the study. It is granted throughout the country, thus also available to beneficiaries from small towns. The appearance of this relationship as a key one was indicated by $83.6 \%$ of mayors, but they agreed that it would not exist for more than a few more months. The declared reaction to it was only supplementary information to local entrepreneurs about the availability of this assistance.

A much more durable, expected, new and key animation relationship comes from subsidies for communes for financing investment in the municipal technical and social infrastructure, which will compensate for some of the budget revenue lost as a result of the pandemic, as well as support the country's economy in crisis by increasing the overall demand. Regarding the latter, it should be added that in recent years the investments made by self-governments accounted for approximately $40 \%$ of all public investment expenditure in Poland, which is why they are considered a strategic partner of the state authorities in the implementation of the demand stimulation policy. Thus $60 \%$ of the surveyed authorities expect to receive such subsidies, and half-way through the study, the state authorities announced the creation of The Government Fund for Local Investments (GFLI) (part of the COVID-19 Counteracting Fund with a target value of approximately PLN 100 billion). Based on it, the first package of such subsidies amounted to PLN 6 billion, which two weeks later was raised to PLN 12 billion, while declaring that GFLI will be a permanent mechanism to support investments of communes. The expected stimulating subsidies also include funds from the anti-crisis European Reconstruction Fund (ERF) and the Multiannual Financial Framework 2021-2027 (MFF) now being prepared by the EU. The respondents expect that funds from the MFF will also be focused on investment. The planned changes to the neo-endogenous absorptivity of SPLDSG in relation to this new animation relationship is a focus on the substantive (e.g. feasibility studies, analysis of effects, selection of the best projects) and organizational preparation 
(e.g. updating zoning plans, unscrambling properties ownerships, training municipal project managers) of communes and their organisational entities and companies to the expected absorption.

The third of the expected new animation relationship (27.2\% of responses) is the pandemic-induced influx of new inhabitants to small towns, including the reemigration of those who, for the previously described reasons, permanently left them after the system transformation began. The surveyed authorities attach exceptional importance to this relationship, even if it were to be counted only in hundreds of people. They see in it both the inflow of human, social and material capital belonging to migrants (including even their companies), as well as the reputational breakthrough of the long-term, negative migration and natality. The expectation of its occurrence is based mainly on the expectations of the development of the new valorisation relationship in the field of telework, as discussed above. Additionally, with regard to re-emigration, the mayors pointed to the pandemic-induced decline in the attractiveness of labour markets in Western Europe, where a significant part of provincial Poland's inhabitants migrated after accession to the EU. The prepared reaction in the area of SPLDSG' neo-endogenous absorptivity is primarily changes in zoning plans increasing the possibilities of residential construction, infrastructural preparation and sale of municipal land, development of social infrastructure important for people of mobile productive age (especially kindergartens, schools, sports and recreational facilities - and with the use of GFLI), as well as lobbying and support for the development of communication services and infrastructure connecting them with the nearest large cities.

The next in terms of the number of responses (10.9\%) was the relationship of the inflow of foreign direct investments (FDIs), based on the previously discussed expectation of production relocation to safer and sufficiently efficient locations, which was to precede the development of new industrial functions. The adjustment of SPLDSG in this respect is to consist in acquisition as well as legal and infrastructural preparation of real estate for investments (with the use of GFLI) and investment marketing carried out in cooperation with The Polish Investment and Trade Agency, which supports FDIs.

The expectations included the inflow of new teleservices to residents and enterprises provided by distant entities $(9.1 \%)$, and constituting their response to the pandemic (e.g. new types of e-commerce, distance learning, telemedicine, e-administration), as well as the inflow of knowledge and innovations created around the world as a response to the pandemic (e.g. new digital technologies, organizational patterns of telework, epidemic safety practices). The surveyed authorities plan to support these animation relationships through training and other forms of social education.

The remaining expectations of pandemic-induced changes in animation relationships were expressed very rarely and focus on the emergence of: a virtual inflow of supralocal, highly qualified personnel to local enterprises $(3.6 \%)$ as a result 
of the already described advancing delocalisation of work; housing investments of external developers $(5.4 \%)$ in response to the influx of new residents; state residential rent subsidies and other social assistance for residents who have lost their jobs or income as a result of the pandemic (3.6\%); influx of patterns of civic attitudes constituting the reactions of other local communities to the pandemic $(3.6 \%)$. The investigated authorities do not plan to adapt their SPLDSG to these new relationships.

\subsection{Expected (or observed) changes in suppression relationships and planned response in the protectiveness of SPLDSG}

The new suppression relationship, considered crucial by $100 \%$ of the surveyed authorities, is a series of lockdown-type restrictions introduced throughout the country by the state authorities since the beginning of the pandemic and aimed at slowing it down. These measures included: cancelling mass events, radical limiting non-family gatherings and international travel, introducing compulsory quarantine for those returning from abroad or having contact with those infected, forbidding non-essential domestic travel and outdoor activities, forbidding unaccompanied minors from leaving their homes, implementing limits in shops, requiring individuals walking in streets to be separated by two metres, prohibiting access to forests, cancelling classes in schools and universities, closing hotels, parks, boulevards, beaches, hairdressers, beauty salons, philharmonic orchestras, operas, theatres, museums, cinemas, etc. The possibility of imposing additional local restrictions was also introduced. The mayors indicated that these restrictions, together with the recommendations for additional voluntary social distancing, strongly and sometimes permanently limited the economic and social process of their towns, and at the same time negatively affected the local factors of these processes, especially social capital. They also suspended or significantly impeded the activity of the commune authorities, the town hall, organizational units and companies owned by the commune, including activities critical from the point of view of LD governance, such as the adoption of resolutions by the council, the provision of basic administrative services and the conclusion of contracts with partners. Importantly, about every fourth mayor expressed doubts as to whether the broadly understood costs of introducing restrictions were greater than the benefits they brought, especially in small towns. By the time of the study, most of these restrictions had been abolished or loosened, but the surveyed authorities expect them to be partially and periodically reintroduced over the next months and even years in view of the likely new pandemic waves and the long-term prospects for vaccine or drug development.

The declared changes in SPLDSG' protectiveness, which are a response to this suppression, can be divided into two groups. The first one, declared by $94.5 \%$ of the respondents, is to ensure significantly higher standards of epidemiological safety than before the pandemic of institutions, buildings and public spaces belonging to the commune, as well as the epidemiological education of residents and municipal 
employees. Obviously these actions do not affect country-wide restrictions, but they reduce the risk of local outbreaks and the introduction of local suppressive restrictions by the State Sanitary Inspectorate, such as shutting down public and private entities and implementing compulsory quarantine. They are also intended to reduce the likelihood of imposing a quarantine on the entire commune, which would result in its socio-economic collapse, and which is to be allowed by a new law prepared by the government to make the fight against the pandemic more "territorially intelligent".

Protection actions from the second group are not aimed at reducing suppressive limitations, but at compensating for their negative effects. As for enterprises, $41.9 \%$ of small town authorities declare their introduction, extension or deepening. These are mainly tax exemptions in real estate, agricultural, forestry and means of transport, constituting the incomes of communes, as well as a reduction of payments for the rental of business premises and other communal real estate, and finally deferred repayment of other civil law liabilities. These tools are bundled together and referred to as "Local Anti-Crisis Shields" (LACS). With regard to the local community, 23.6\% of the authorities are planning to continue or implement various activities to reactivate social contacts, strengthen mutual trust, promote anti-pandemic civic attitudes, encourage reengagement in social activities and motivate to resume recreational, sports and cultural activities, etc. Significantly, in $12.7 \%$ of cases it is planned to maintain (introduced at the beginning of lockdown) remote forms of providing cultural, educational, social and administrative services, or to implement new ones. A special subgroup of compensatory actions are those that local authorities intend to undertake for their own administrative structures. Their implementation is declared by $100 \%$ of the respondents. They consist primarily in the implementation of effective work procedures in the conditions of a pandemic recurrence and national lockdown, as well as the replacement of public governance instruments ineffective in the new socio-economic reality with new ones, e.g. cancelling participation in international investment fairs in favour of organizing study visits of investors and intensifying direct marketing.

The second largest pandemic-induced suppression relationship $(34.5 \%$ of the responses) was the inflow from supralocal environment to the town and the replication in it of psychological factors, destructive for local social capital. This concerns the pandemic-induced atmosphere of anxiety for the health of oneself and one's relatives, the need to use the overburdened health care, re-restrictions limiting the pandemic, economic crisis, job loss, drop in income, loss of material security, the need to give up personal plans, succumb to isolation and social distancing, social unrest and protests, limitation of civil liberty, and even the atmosphere of uncertainty about the future of the country, the EU and the world. This also regards the national atmosphere of additional socio-political conflict, and even signs of legal chaos, resulting from the coincidence of the pandemic with the presidential campaign and election (when voting did not take place on the scheduled date of May 10 and was postponed to 28 June and 12 July). This suppression relationship has waned as the national pandemic situation improved, restrictions were loosened and the elections 
were held, but the authorities surveyed saw its continued presence and the risk of it occurring again. As with state restrictions, however, they cannot reduce it. Few of them $(9.1 \%)$ plan to compensate for its effects by engaging residents in mutual assistance, civic education, promoting civic attitudes and an approach in line with the slogan "think globally, act locally", that is by strengthening local social capital.

The SARS-CoV-2 virus itself was indicated as the present and expected key suppressive factor by only six respondents (10.9\%). This means that there are several times more of those who perceive restrictions as being strategically damaging to the LD of their towns than those who perceive in this way the inflow of the virus to the town. This is most likely due to the fact that at the start of the study, the number of confirmed cases in Poland was less than 30,000. (including approximately 14,000 active and 1,256 deaths), i.e. approximately 790 cases per 1 million population, and the vast majority of them occurred in large and medium-sized cities. However, as already indicated, the percentage of authorities that will ensure a significantly higher standard of epidemic safety and epidemic education of residents than before the pandemic is $94.5 \%$.

Among the reported pandemic-induced changes in suppression relationships, there is also an increase in Internet crime and other online offences committed by supralocal perpetrators against local seniors, i.e. people most at risk of COVID-19 (7.2\% of responses). Many of them, along with the "stay-at-home" call and prioritizing social distancing, initiated or intensified their Internet presence in order to maintain social contacts, especially family ones, used for purposes that are illegal or against the general principles of social coexistence. All of the mayors who pointed to this relationship expect it to continue. Therefore, as part of SPLDSG' protectiveness, they intend to develop the digital competences of seniors through training and other forms of education.

Among the indications of the surveyed authorities for key changes in the suppression relationships was also the weakening of the few that existed before the pandemic. The state's ACS widened the permissible scale of the current imbalance in the budgets of communes, increased the limit of their allowable debt, and also enabled previously unacceptable shifts of funds between certain types of expenditure. Normally, legal suppression in these areas serves to implement state financial policy and reduces the risk of strategic financial mistakes by the local authorities, but limits their ability of LD governance. On the onset of the pandemic, the government decided to ease it, and $20 \%$ of the mayors believe that this change is important and will be maintained in the coming months or years, and even that it will be deepened. The planned response is the use of periodically available financial instruments in SPLDSG.

\subsection{Expected (or observed) changes in depreciation relationships and planned response in the retentiveness of SPLDSG}

Pandemic-induced, significant changes in the structure of depreciation relationships are rarely noticed by the surveyed authorities, but if anything, these are mainly changes favourable from the point of view of their towns. 
The most frequently mentioned of them (21.8\% of the respondents) turned out to be the periodic reduction in state public dues introduced by the ACS. This mainly covers economic entities and has the form of exemptions from contributions for compulsory social, health and retirement insurances, tax exemptions and deferrals, write-offs of tax arrears, enabling the deduction of losses for 2020 from income for 2019, as well as a reduction to $5 \%$ of the tax rate on intellectual property rights used to counteract the pandemic. However, all the respondents expect that these depreciation relationships will return to its original normal form in no more than some months. In view of its temporary weakening, the examined local authorities do not plan any actions. The interested beneficiaries are in their opinion, satisfactorily informed by the state. In this respect, their SPLDSG will remain neutral.

The second positive change, indicated by $18.2 \%$ of the mayors, is the decline in the prices of services provided by supralocal construction companies. This occurred shortly after the pandemic began in Poland and reached an average value of several percent, which means savings for communes, being important customers in this market. This is not a typical depreciation relationship because it is accompanied by the equivalent in the form of a construction service, but it causes a partial increase in the relative value of communal financial resources, which is one of the important factors of LD. According to the respondents, this change will not be permanent and the communes are not able to react to it. However, they believe that it will contribute to the short-term balance of their budgets, whose revenues have decreased due to the crisis weakening of the local economy (especially due to the observed weakening of the valorisation relationships) and the use of fiscal instruments to support it as part of the exogenous utilitarianness of the SPLDSG.

Slightly over $16 \%$ of small town authorities perceive a decrease in the cost of capital borne by credit recipients as a favourable change in the depreciation relationships. This results from the three-fold reduction of the reference rate by the National Bank of Poland to the final level of $0.1 \%$ in the first three months after the introduction of anti-pandemic restrictions. The purpose of this unprecedented cut in the reference rate is to stimulate the crisis economy by reducing the price of money and increasing its supply. The mayors who indicated it expect it to be sustainable in the long term. Their declared strategic reaction is a slight increase in the commune's debt to increase infrastructure investments. They expect that the costs of capital that the commune will incur in the new reality will be significantly lower than those they would have incurred in the previous conditions.

A long-term surge of inflation is an unfavourable change in the depreciation relationship, expected by $18.2 \%$ of the respondents. This expectation is based on the belief that the government's policy of increasing internal demand with social transfers, subsidies to enterprises and lowering interest rates will trigger a noticeable, long-term increase in the prices of goods and services, despite the crisis overall decline in demand. However, they do not have the possibility of reacting to this 
change other than raising this threat in institutionalized forums for dialogue between the government and self-governments.

On the other hand, a favourable expected change in the depreciation relationships is a slight reduction in emigration, especially of young residents who completed their studies by commuting to nearby, big-city universities. This expectation was expressed by $9.1 \%$ mayors, and it was motivated by the above-mentioned arguments of the popularization of telework, teleservices and e-commerce. The retention support of a more favourable, i.e. lower levels of this relationship, is to be served by the same planned actions of the surveyed authorities to intensify the already discussed animation relationship - the influx of new residents and the re-emigration of the former ones. Therefore the new retentiveness of SPLDSG is in this respect identical to its neo-endogenous absorptivity.

\subsection{Main characteristics of overall picture of expectations (and observations) towards pandemic-induced changes in supralocal relationships and planned (or implemented) responses in the SPLDSG}

The above-discussed, expected or already noted by Polish local authorities, pandemic-induced changes in the supralocal relationships of the small towns as well as the planned or already taken responses to them within the SPLDSG, are synthetically presented in Tables 1 and 2 . Their overall picture has some interesting characteristics.

Table 1. Changes in valorisation and animation relationships expected (or observed) by Polish authorities of small towns and their planned (or implemented) response in SPLDSG

\begin{tabular}{|c|c|c|c|}
\hline \multicolumn{2}{|c|}{ Valorisation relationships } & \multicolumn{2}{|c|}{ Animation relationships } \\
\hline 1 & $\underline{2}$ & 3 & $\underline{4}$ \\
\hline $\begin{array}{l}\text { change expected } \\
\text { or/and } \\
\text { already observed }\end{array}$ & $\begin{array}{c}\text { planned (implemented) } \\
\text { response in exogenous } \\
\text { utilitarianness } \\
\text { of SPLDSG }\end{array}$ & $\begin{array}{l}\text { change expected } \\
\text { and/or } \\
\text { already observed }\end{array}$ & $\begin{array}{c}\text { planned (implemented) } \\
\text { response in neo- } \\
\text {-endogenous } \\
\text { absorptivity } \\
\text { of SPLDSG }\end{array}$ \\
\hline $\begin{array}{c}\begin{array}{l}*: * \quad(34.5 \%) \\
\text { decline in supralocal }\end{array} \\
\frac{\text { demand for local goods }}{\underline{\text { s services }}}\end{array}$ & 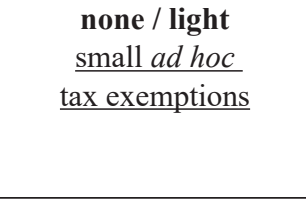 & 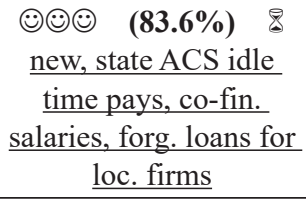 & $\begin{array}{c}\text { Light } \\
\text { supplementary } \\
\text { information to local } \\
\text { companies on state } \\
\text { assistance }\end{array}$ \\
\hline $\begin{array}{c}-(-) \quad(50.9 \%) \\
\text { increase in supralocal } \\
\text { demand for local } \\
\text { tourist services }\end{array}$ & $\begin{array}{l}\text { moderate / strong } \\
\text { constr. touristic infr., } \\
\text { revit., zoning plans, } \\
\text { promotion } \\
(3.6 \% \text { terr. spec. / } \\
16.4 \% \text { comp. to other } \\
\text { exog. func. })\end{array}$ & $\begin{array}{c}\text { (:) }(\mathbf{6 0} \%) \quad 8 / 8 \% \\
\text { new, state }(\mathrm{GFLI}) \\
\text { \& EU (ERF, MFF) } \\
\text { support for communes' } \\
\text { investments }\end{array}$ & $\begin{array}{c}\text { Moderate } \\
\text { feasibility studies, } \\
\text { zoning plans, } \\
\text { unscrambling } \\
\text { properties ownerships, } \\
\text { training project } \\
\text { managers }\end{array}$ \\
\hline
\end{tabular}




\begin{tabular}{|c|c|c|c|}
\hline 1 & 2 & 3 & 4 \\
\hline $\begin{array}{l}(\mathbf{3}) \mathbf{3} \%) \quad 888 \\
\text { new telework by } \\
\text { residents for } \\
\text { supralocal employers }\end{array}$ & $\begin{array}{c}\text { Moderate } \\
\text { constr. network } \\
\text { infrastructure, co- } \\
\text { working spaces, } \\
\text { entrepreneurship } \\
\text { incubators, railway } \\
\text { lobbying }\end{array}$ & $\begin{array}{l}(\mathbf{2 7 . 2 \% )}) \\
\text { new influx of } \\
\text { inhabitants to small } \\
\text { towns, including the } \\
\text { re-emigration }\end{array}$ & $\begin{array}{c}\text { Moderate } \\
\text { zoning plans, prep. } \\
\& \text { sale of land, dev. } \\
\text { of social infrastructure., } \\
\text { lobbying for } \\
\text { communication } \\
\text { services and } \\
\text { infrastructure }\end{array}$ \\
\hline $\begin{array}{l}(\mathbf{1 0 . 9} \%) \quad 8 \% 8 \\
\text { new industrial } \\
\text { production for } \\
\text { supralocal clients }\end{array}$ & $\begin{array}{l}\text { moderate / strong } \\
\text { acquiring and } \\
\text { preparation of real } \\
\text { estates for foreign } \\
\text { direct investments, } \\
\text { investment marketing }\end{array}$ & $\begin{array}{l}\text { (:) } \mathbf{( 1 0 . 9 \% ) ~} 8 \% 8 \\
\text { new inflow of foreign } \\
\text { direct industrial } \\
\text { production investments }\end{array}$ & $\begin{array}{l}\text { moderate / strong } \\
\text { acquiring and } \\
\text { preparation of real } \\
\text { estates for foreign } \\
\text { direct investments, } \\
\text { investment marketing }\end{array}$ \\
\hline \multicolumn{2}{|c|}{$\begin{array}{l}\text { (single indications with no response) } \\
- \text { intensification of subregional trade, } \\
- \text { new culture services for supr. audience }\end{array}$} & $\begin{array}{l}\text { (:) } \mathbf{( 9 . 1 \% )} 88 \% \\
\text { inflow of new } \\
\text { teleservices to residents } \\
\text { \& enterprises by distant } \\
\text { entities }\end{array}$ & $\begin{array}{l}\text { Light } \\
\text { training and other } \\
\text { forms of social } \\
\text { education }\end{array}$ \\
\hline & & \multicolumn{2}{|c|}{$\begin{array}{l}\quad \text { (single indications with no response) } \\
- \text { new virtual inflow of HQ staff to local firms, } \\
- \text { new housing investments of ext. developers, } \\
- \text { new res. rent subsidies \& oth. social } \\
\text { assistance, } \\
- \text { influx of unknown before pandemic civic } \\
\text { attitudes }\end{array}$} \\
\hline
\end{tabular}

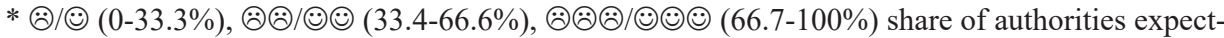
ed new relationship or change of previously existing one as crucial and negative/positive for LD of their small towns.

$* * \&$ short-, $8 \%$ medium-, $8 \% 8$ long-term expected duration of a new relationship or the new state of the previously existing one.

Source: own elaboration.

Firstly, the negative changes in the discussed relationships in the opinion of these authorities, are primarily the intensification of the suppression relationships, especially those administrative (in the sense of public administration), the source of which is the state (restrictions slowing down the pandemic), and psychological, the source of which are supralocal communities (uncertainty, fears for the future, etc. affecting local social capital). The reduction of the valorisation relationships and the increase of the depreciation relationships are indicated much less frequently and relate respectively to the medium-term decrease in the supralocal sales of local goods and services and the long-term increase in inflation.

Interestingly, none of the surveyed authorities expect any significant reduction in any of the animation relationships. On the contrary, they all expect a significant 
Table 2. Changes in depreciation and suppression relationships expected (or observed) by Polish authorities of small towns and their planned (or implemented) response in the SPLDSG.

\begin{tabular}{|c|c|c|c|}
\hline \multicolumn{2}{|c|}{ Depreciation relationships } & \multicolumn{2}{|c|}{ Suppression relationships } \\
\hline $\begin{array}{l}\text { change expected or/and } \\
\text { already observed }\end{array}$ & $\begin{array}{c}\text { planned (implemented) } \\
\text { response } \\
\text { in retentiveness } \\
\text { of SPLDSG }\end{array}$ & $\begin{array}{l}\text { change expected or/and } \\
\text { already observed }\end{array}$ & $\begin{array}{c}\text { planned (implemented) } \\
\text { response } \\
\text { in protectiveness } \\
\text { of SPLDSG }\end{array}$ \\
\hline $\begin{array}{c}\mathbf{( 2 1 . 8 \% )} \\
\text { periodic reduction in } \\
\text { state public dues } \\
\text { introduced by ACS }\end{array}$ & None & $\begin{array}{l}\theta:(\mathbf{1 0 0 \% )}) \\
\underline{\text { lockdown-type broad }} \\
\underline{\text { restrictions introduced }} \\
\text { by state authorities }\end{array}$ & \begin{tabular}{|c} 
Strong \\
$\underline{\text { high standard of }}$ \\
epidemic safety, LACS \\
social \& human capital \\
streng., new tools of \\
LD governance
\end{tabular} \\
\hline $\begin{array}{c}\text { (18.2\%) } \\
\text { decline in prices of } \\
\text { construction services } \\
\underline{\text { by supralocal firms }}\end{array}$ & e & $\begin{array}{l}\text { :) } \begin{array}{c}(34.5 \%) \\
\text { inflow of the }\end{array} \\
\text { psychological factors, } \\
\frac{\text { destructive for local }}{\text { social capital }}\end{array}$ & $\begin{array}{c}\text { none / light } \\
\text { engaging residents } \\
\text { in mutual assistance } \\
\text { civic education and } \\
\text { promotion }\end{array}$ \\
\hline $\begin{array}{c}\begin{array}{c}(16 \%) \\
\text { decrease in the cost of }\end{array} \\
\frac{\text { capital borne by credit }}{\text { recipients }}\end{array}$ & $\begin{array}{l}\text { Light } \\
\text { slight increase in the } \\
\text { commune's debt to } \\
\text { increase infrastructure } \\
\text { investments }\end{array}$ & $\begin{array}{l}\text { : }(\mathbf{1 0 . 9 \% )} \\
\text { influx of SARS-CoV-2 } \\
\text { virus from supralocal } \\
\text { environment to the } \\
\text { town }\end{array}$ & $\begin{array}{c}\begin{array}{c}\text { Moderate } \\
\text { ensuring significantly }\end{array} \\
\underline{\text { higher standard }} \\
\begin{array}{c}\text { of epidemic safety } \\
\text { and epidemic education }\end{array} \\
\underline{\text { of residents }}\end{array}$ \\
\hline $\begin{array}{l}\text { (:) }(\mathbf{9 . 1 \% )} \\
\text { slight reduction in } \\
\text { emigration, especially } \\
\text { of young residents }\end{array}$ & \begin{tabular}{|c} 
Moderate \\
zoning plans, prep. \\
\& sale of land, dev. \\
of social infr., lobbying \\
for communication \\
services and infrastr.
\end{tabular} & $\begin{array}{l}\text { (7.2\%) } 8 \% \\
\text { increase in } \\
\underline{\text { Internet crimes }} \\
\underline{\text { against local seniors }}\end{array}$ & \begin{tabular}{|c} 
Light \\
developing digital \\
competences of seniors \\
through training \\
\& other education
\end{tabular} \\
\hline $\begin{array}{l}8 \quad(\mathbf{1 8 . 2 \% )}) \\
\text { surge of inflation as } \\
\underline{\text { result of gov.'s policy }} \\
\underline{\text { of increasing demand }}\end{array}$ & $\begin{array}{l}\text { none / light } \\
\text { debates at forums } \\
\text { for dialogue of the } \\
\text { government and self- } \\
\text {-governments }\end{array}$ & $\begin{array}{c}\begin{array}{c}(\mathbf{2 0} \%) \\
\text { loosening state legal }\end{array} \\
\text { suppression in the field } \\
\text { of municipal finance }\end{array}$ & $\begin{array}{c}\text { light } \\
\text { use of periodically } \\
\text { available financial } \\
\text { instruments in } \\
\text { SPLDSG }\end{array}$ \\
\hline
\end{tabular}

$*, * *$ - the symbols as in Table 1.

Source: own elaboration.

increase in this type of relationships, again most often administrative, related to short-term (ACS) and medium-term (stimulating demand with public investments) support from the state. Adding to this picture the fact that a long-term loosening of some administrative financial suppressions also has an administrative nature, it can be concluded that for the examined authorities, the main short and medium-term pandemic-induced factor of both favourable and unfavourable changes in the supralocal relationships of their towns are the state authorities and their policies. 
Particularly noteworthy are the expectations of the long-term changes in the animation and valorisation relationships resulting from pandemic-induced social and market processes. First of all, this is about a new influx of new inhabitants and FDIs to small towns, an increase in their exogenous tourist and industrial production functions and a two-way development of telework streams. Their basic sources, in the opinion of the respondents, will be or already are: global restrictions, the multi-dimensional prioritization of social distance, the mental and market change promoting telework, restructuring of tourist demand, and the decline in the reliability of long global supply chains. Although the expectations of these changes in supralocal relationships were expressed less frequently than those caused by the government, all of them are changes favourable to LD and permanent.

The planned reactions of the authorities expecting such favourable changes in the supralocal situation are mainly active, not passive, and concern mostly the neo-endogenous absorptiveness and exogenous utilitarianness of the SPLDSG. In the area of neo-endogenous absorptiveness, they focus on increasing the ability of their towns to neo-endogenously receive state and EU aid (ERF, MFF), which will increase their ability to receive new residents and investors developing its exogenous functions. The primary absorption of the state' animating factor is therefore not so much to reduce the pandemic-induced relationships of suppression and depreciation, or to compensate for their effects, but to enable the next absorption of the factors resulting from the pandemic-induced socio-economic changes, and ultimately to stimulate the development of such a structure of the valorisation relationships that matches the post-pandemic demand structure. This can be described as a strategy of sequential absorption for the development of exogenous functions. The exogenous utilitarianness of their SPLDSG is also subordinated to this strategy. Within it, but this time based on their own resources and low-cost credit, they want to support the same valorisation relationships, sometimes until they are given the role of territorial specializations.

However all the authorities, including those that do not expect such changes in their supralocal strategic position, declare a strong protective response to the pandemic. There is a unanimous opinion among them that despite the current slowdown, it will continue for at least a dozen or so months, increasing periodically, but this reaction is much more likely to compensate for the local socio-economic effects of state restrictions limiting its spread than to protect against the virus itself.

\section{Discussion and conclusions: are the expected changes important and beneficial, and would they, when combined with the new SPLDSG, have significant stimulating potential in terms of small towns' LD?}

The identified image of the expectations of Polish local authorities as to the pandemic-induced changes in the supralocal relationships of their small towns is the image 
of their supralocal situational awareness that they showed during the research. Yet pandemic-induced global changes have only recently started and are still ongoing, so only the future will show to what extent these expectations are reflected in reality. Of particular importance here is not only following socio-economic changes with the expected trajectories, but also the consistency of the state authorities in the implementation of the current declarations. Nevertheless, they have their logical foundations carried out by these authorities, which are constant observation of supralocal reality and directions of its changes, as well as their own and obtained forecasts and cause-and-effect analyses. They are also confirmed in scientific forecasts of post-pandemic reality (see e.g. Baert, Lippens, Moens, Sterkens, and Weytjens, 2020, pp. 14-15; Gössling, Scott, and Hall, 2020, pp. 13-15; EU Joint Research Centre, 2020, p. 8; International Labour Organisation, 2020, pp. 3-4). It is also impossible to underestimate the fact that they were expressed by mayors representing entire local authorities, cooperating with numerous public governors and managers, knowing their cities very well and having knowledge and experience in the SPLDSG. Put together, this means that the identified picture of expectations (and observations) and planned SPLDSG reactions has a scientific value and allows the following conclusions to be drawn.

Firstly, the research results lead to concluding that the differences between the previous (presented in Section 3) and expected (or already observed), pandemic-induced supralocal relationships of Polish small towns are significant and positive for their LD. The first difference is the emergence of new animation relationships, namely medium-term financial support for local investment by the state (GFLI), but above all the long-term inflow of external investors and residents, the key reasons of which are to be the pandemic-induced global migration of capital and the popularisation of telework. The second difference concerns the valorisation relationships. Although as a result of the Polish systemic transformation they were lost by the majority of small towns and then partially and laboriously rebuilt, now, as a result of the described relationships of animation, the prioritization of social distancing and the transformation of both domestic and foreign tourist demand are to develop more dynamically. As for suppression relationships, anti-pandemic restrictions are a new important element, but while they are expected to be recurrent, they will be weaker than just after the pandemic's outbreak. Moreover, the loosening of the current financial restrictions is expected to continue. In the area of depreciation relations, the expected differences, apart from the increase in inflation, are also positive and concern mainly the slowing down of the outflow of residents and the decline in the costs of lending and of construction services. Combining these expected differences, it can be concluded that in the minds of the surveyed authorities, the pandemic has started to and will further deepen the ultimately beneficial strategic discontinuity in the supralocal situation of their towns.

The research results also allow to conclude that the surveyed authorities intend to actively and comprehensively react to the expected changes in the supralocal situation 
of their towns. Future plans for SPLDSG's alteration are still general, but the promising strategy of sequential absorption for the development of exogenous functions is emerging from them. In turn, the prepared instruments include strong tools for shaping supra-local relationships, such as investment in technical, social and business infrastructure, new zoning plans, supralocal promotion, multidimensional education, as well as lobbying for and support for the development of passenger transport linking with big cities. The general commitment of the surveyed authorities in responding to the changes is also of great importance, and also the declarations of most of them that they will immediately develop, formally adopt and comprehensively implement new local development strategies corresponding to the new situation. It is worth noting here that the beginning of the pandemic-induced changes coincided with the introduction of the commune development strategy by the state authorities to Polish local government law for the first time (June 2020). This is to increase their quality and serve to link state and EU (ERF, MFF) support to a good LDSG, as well as to generally encourage it.

Taken together, the results of the research allow for the third conclusion that the expected (and observed) changes in the supralocal relationships of Polish small towns combined with the planned corresponding reactions of their authorities within the SPLDSG, have in general a high stimulating potential in terms of LD. The materialization of the identified expectations would mean a structural, beneficial change in the supralocal strategic position of Polish small towns. After a short or medium-term relatively minor crisis, in the long run these towns would then turn out to be beneficiaries of pandemic-induced supralocal socio-economic changes. The inner, most important condition, is an appropriate reaction not only in terms of strategy selection and crystallization, but also its implementation. For many of them, this would mean breaking the negative trend of shrinkage which had its source back in the systemic transformation of the 1990s, and replacing it with economic and social development, including its demographic dimension. Most of the surveyed authorities believe in this opportunity.

The research results also allow for the formulation of assumptions about the authorities of communes not covered by the research. First, it can be assumed that one can find analogous expectations towards changes in the supralocal relations and SPLDSG modification plans in those Polish rural communes whose largest villages have the characteristics of a small town but not the formal status of a town, of which there are at least several dozen. Secondly, it is reasonable to suppose that similar expectations and plans also apply to local authorities in small towns from other $\mathrm{CEE}$, post-communist, similarly decentralized countries. Many of these towns also underwent transformational shrinkage (e.g. in the Czech Republic, Hungary, and Slovakia), and their countries today have a geopolitical situation similar to that of Poland, and are considering similar anti-crisis policies. Significant and beneficial for $\mathrm{LD}$, the pandemic-induced changes of the supralocal determinants and the corresponding activities within SPLDSG may thus refer to a much larger number of towns than those covered by this research, and may have an international scale. 


\section{Recommendations}

The identified image of the expectations of Polish local authorities towards the pandemic-induced changes in the supralocal relationships of their small towns and the planned responses to them in the SPLDSG, as well as the conclusions drawn from them, may have several applications.

Firstly, the presented research results may be useful for the local authorities of small towns and other similar units. For such Polish authorities, this is useful information about the ways of perceiving the pandemic-induced changes in supralocal relationships and patterns of reacting to them currently crystallizing in their environment. For similar authorities in other countries it can serve as a point of reference and motivation to seek their own strategies of adaptation to the new reality.

Secondly, the knowledge contained in the picture of the expectations and strategic intentions of small town authorities may also be useful for the creators of the Polish (and maybe not only) state anti-crisis policy of development. Faced with the crisis-induced investment reluctance of the private sector, the government needs local governments as co-implementers of the policy of stimulating internal demand through investment as national institutions and state-owned enterprises alone are not enough. However, in order for the supported investments to bring not only a short-term demand-side effect, but essentially long-term LD (by increasing small towns' competitiveness, resilience, sustainability, etc.), it is necessary to adapt them to the pandemic-induced structural changes and make them neo-endogenic, i.e. enduringly integrated with local values. When defining the directions and conditions of support, it is therefore worth taking into account the situational awareness of local authorities, including those examined, and their SPLDSG update plans, to make both approaches consistent, according to the idea of multilevel governance. This will also increase their role in LD processes perceived from the supralocal perspective.

Not all the authorities of small towns are equally professional in the SPLDSG. Combined with the expected deep changes in supralocal relationships, the intention to actively shape them and the new law in the field of communal strategies, this may lead to strategic multi-dimensionally costly mistakes. Therefore, the third recommendation concerns the implementation of programs facilitating substantive, long-term, individualized support for the said authorities in preparing and implementing their new LD strategies. This support should be provided jointly by government, universities and consulting where the SPLDSG is carried out, i.e. in the seats of these authorities and directly to these authorities. The incidental standardized support addressed mainly to mid-level staff - performed so far - will not result in the desired effect.

Disseminating knowledge about local development strategic governance, including SPLDSG, should also apply to university studies related to public governance. The results of the conducted research can be used as a case study of attempts to observe and actively use LD opportunities in a new and unexpected dynamic supralocal situation, hitherto perceived only negatively by the vast majority. 
The results of the research are also an example of the long-term effects of the practical application of the idea of localism, consisting in the functioning of numerous local authorities committed to and able to create LD and thus contributing to the development of the country also in the event of sudden socio-economic structural changes. In countries where power and development policies are not decentralized to the local level, this example can be used to discuss the legitimacy of such decentralization.

The final recommendation concerns further research. For analogous applications, similar research should be carried out on the authorities of small towns in other countries, in which they are capable of real LD governance, especially in the aforementioned post-communist CEE countries. Moreover, after research identifying expectations regarding changes in supralocal relationships, the emphasis should be placed on the identification of actual changes as they intensify. Research should also be carried out to identify the effects of particular reactions or strategic SPLDSG models applied by local authorities to the pandemic-induced changes in their supralocal environment. It is also worth identifying which of the local authorities have adopted a passive attitude and why. Taken together, such research will provide knowledge useful in the practice of public governance and in developing its theory.

As part of the larger project, the presented research will be continued one year after its first edition. Its aim will be to verify which expectations have been confirmed , what first effects were brought by the new SPLDSG adjusted to them, and whether Polish small towns generally benefited from the pandemic-induced changes in their supralocal relationships.

\section{References}

Baert, S., Lippens, L., Moens, E., Sterkens, P., and Weytjens, J. (2020). The COVID-19 crisis and telework: A research survey on experiences, expectations and hopes. IZA Institute of Labor Economics Discussion Paper Series, (13229), 1-37.

Bober, J., Hausner, J., Izdebski, H., Lachiewicz, W., Mazur, S., Nelicki, A., Nowotarski, B., Puzyna, W., Surówka, K., Zachariasz, I., Zawicki, M. (2013), Narastajace dysfunkcje, zasadnicze dylematy, konieczne działania. Raport o stanie samorzadności terytorialnej w Polsce. Kraków: Wydawnictwo Uniwersytetu Ekonomicznego w Krakowie, Małopolska Szkoła Administracji Publicznej.

Blair, F., and Evans, B. (2004). Seeing the bigger picture: Delivering local sustainable development. York: Joseph Rowntree Foundation.

Bukowski, S. (2020). Nie przetrwamy bez pomocy państwa! Retrieved April 17, 2020 from www. wspolnota.org.pl

EU Joint Research Centre. (2020). Telework in the EU before and after the COVID-19: Where we were, where we head to. European Union, JRC120945, 1-8.

Frisken, F., and Wolfson, J. (2000). Local response to the global challenge. Comparing local economic development in a regional context. Journal of Urban Affairs, 4(22), 361-384.

Gniadkowski, A. (2020). Programy i strategie samorządów będzie trzeba zmienić. Wspólnota, (7/1299), 40-41.

Gössling, S., Scott, D., and Hall, C. M. (2020). Pandemics, tourism and global change: A rapid assessment of COVID-19. Journal of Sustainable Tourism, 1-20. 
International Labour Organisation. (2020). The effects of COVID-19 on trade and global supply chains. Geneva: ILO Brief.

Kantor-Pietraga, I., Krzysztofik, R., and Runge, J. (2012). Kontekst geograficzny i funkcjonalny kurczenia się małych miast w Polsce południowej. In K. Heffner, A. Halama (Eds.), Ewolucja funkcji matych miast w Polsce. Katowice: Wydawnictwo Uniwersytetu Ekonomicznego w Katowicach.

Kuotsai, T. L. (2009). Local economic development in China and the United States: Strategies and issues. Public Administration Review - Supplement S1, (69), 29-37.

Lewis, P. G. (2001). Looking outward or turning inward? Motivations for development decisions in California central cities and suburbs. Urban Affairs Review, 36(5), 696-720.

Marques, H. R. (2009). Desarrollo local a escala humana. Polis. Revista Latinoamericana, (22), 1-18.

Milán-García, J., Uribe-Toril, J., Ruiz-Real, J. L., and Valenciano, J. P. (2019). Sustainable local development: An overview of the state of knowledge. Resources, 8(1), 1-18.

O'Brien, P., Sykes, O., and Shaw, D. (2015). The evolving context for territorial development policy and governance in Europe - from shifting paradigms to new policy approaches. L'Information géographique, 1(79), 72-97.

Rezsohazy, R. (1988) Le développement des communautés. Louvain-la-Neuve: CIACO Editeur.

Sobańska-Cwalina, M. (2020). E-prowincja. Czy koronawirus może stać się szansa dla mniejszych miejscowości? Retrieved April 20, 2020 from www.forbes.pl

Szajnowska-Wysocka, A. (2009). Theories of regional and local development - Abridged review. Bulletin of Geography. Socio-Economic Series, (12), 75-90.

Sztando, A. (2017a). Ponadlokalna perspektywa zarządzanie strategicznego rozwojem lokalnym na przykładzie małych miast. Wrocław: Wydawnictwo Uniwersytetu Ekonomicznego we Wrocławiu.

Sztando, A. (2017b). Local culture in supralocal perspective of local development strategic governance of small towns. Studia Ekonomiczne, (314), 61-79.

WHO. (2020). Coronavirus disease (COVID-19) (Situation Report, no. 203), August 10.

\section{CZY MALE MIASTA SKORZYSTAJĄ? SPODZIEWANE ZMIANY PONADLOKALNYCH RELACJI POLSKICH MALYCH MIAST WYWOLANE PANDEMIĄ COVID-19 ORAZ PLANOWANE REAKCJE NA NIE W PONADLOKALNEJ PERSPEKTYWIE ZARZĄDZANIA STRATEGICZNEGO ICH ROZWOJEM LOKALNYM}

Streszczenie: Transformacja systemowa lat 90. dla większości polskich małych miast oznaczała głębokie, niekorzystne zmiany ponadlokalnych uwarunkowań ich rozwoju lokalnego. W efekcie zostały one dotknięte wieloma negatywnymi zjawiskami. Pandemia COVID-19 rozpoczęła zmiany społeczno-gospodarcze, których obecna, dominująca ocena jest negatywna. Niemniej dla polskich małych miast, mimo krótkotrwałego ponownego pogorszenia ich ponadlokalnej sytuacji, zmiany te, w dłużej perspektywie czasowej, mogą okazać się korzystne. Artykuł prezentuje zidentyfikowane oczekiwania i obserwacje władz w zakresie pandemicznych zmian relacji łączących ich małe miasta z ponadlokalnym otoczeniem, a także planowane reakcje strategiczne. Wyniki badań doprowadziły do wniosku, że wspomniane zmiany, w połączeniu z planowanymi reakcjami, mają znaczący potencjał stymulacyjny w zakresie rozwoju lokalnego. Artykuł kończą zalecenia wykorzystania zawartych w nim informacji w popandemicznym zarządzaniu strategicznym rozwojem małych miast, w kreowaniu antykryzysowych polityk państw, a także w dydaktyce.

Słowa kluczowe: pandemia COVID-19, rozwój lokalny, ponadlokalna perspektywa zarządzania strategicznego rozwojem lokalnym, małe miasto, Polska. 